\title{
Being a Higher Education Teacher: Living in the Professional Space and Creating the Professional Body
}

\author{
Žydžiūnaitė Vilma ${ }^{1}$, Daugèla Marius ${ }^{2}$
}

1 Vytautas Magnus University, Academy of Education, K. Donelaičio g. 58, LT-44248 Kaunas, Lithuania, vilma.zydziunaite@vdu.lt

2 Vytautas Magnus University, Academy of Education, K. Donelaičio g. 58, LT-44248 Kaunas, Lithuania, marius.daugela@stud.vdu.lt

Abstract. Phenomenological research relies on the position that teaching in higher education should not be considered a duty that just needs to be carried out by the higher education teacher. It is a crucial part of academia, and it is essential that the higher education teacher portrays it as such. The research examined the patterns of the higher education teacher's experiences that are meaningful with regard to the professional body and professional space within higher education.

Keywords: being, higher education, higher education teacher, interaction(s), phenomenology, professional space, professional self, students.

\section{Introduction}

Higher education includes teaching, research, exacting applied work, and social services activities of universities. Within the realm of teaching, it includes the undergraduate and graduate or postgraduate levels. The main aim of higher education is to produce graduates who will be intellectual leaders in their chosen professional path, recognized members in their communities, and responsible citizens. Higher education is under continuous change. This has brought into question what does it mean to be a higher education teacher (HET) and a scholar and the overlapping objectives this entails (Behar-Horenstein, Schneider-Mitchell, \& Graff, 2008). For instance, HETs and scholars experience pressure in terms of scientific productivity, applying and receiving research 
and/or teaching grants, following quality assurance procedures, and adapting to innovations regarding higher education (HE) reforms (Stenfors-Hayes, 2011).

Teaching in HE includes the HET's harmonized knowing and doing, but also the personality of the HET as an important holistic resource. HETs use their individual personalities, attitudes, expectations, experiences, competencies, and perceptions, which impact their teaching as well as students' learning (Dall'Alba, 2005). The HET needs to be aware of his/her own conceptions and to ascertain students' conceptions of teaching and learning. The disciplinary perspectives of both sides, personal and professional experiences and their knowledge can be drawn upon in teaching and learning contexts and situations (Anderson \& Hounsell, 2007). Israeli students provided their opinions about the concept of a "good teacher" in HE (Miron \& Segal, 1978). These students attached primary importance to the method of instruction. Of secondary importance was the teacher's ability to spark intellectual growth. Research talents, personality, and academic status were of relatively little concern. It appears that undergraduate students rate HETs by their ability to transmit knowledge rather than according to the university's criteria of research and publication.

Being a HET is just one of the roles scholars have in HE. Most HETs do not even regard themselves as teachers, but see themselves primarily as researchers (Dall'Alba, 2009). The content of research discipline, which is represented by HETs, affects the way teaching is perceived and conducted, because the particular discipline is connected to concrete discipline-based professional and social contexts (Lindblom-Ylänne, Trigwell, Nevgi, \& Ashwin, 2006). The knowledge that the HET's needs include learning and the sources of knowledge include their academic and professional communities and contexts and professional development (Tight, 2002).

Professional space is lived space by the HET. The space is experienced by raising the following questions: "How does the space shape the HET? How does the HET shape the space?" The space is not the same as the place. The lived space by the HET is experienced internally and externally (van Manen, 2014). The lived space includes the personal aim to become a holistic personality, who is open to the unknown, meaning it is intellectual. The lived space is contemplated and reflected (Anderson \& Hounsell, 2007). The lived professional space reflects the HET's identity, which is developed through three phases: taking on the teacher role, settling into the teacher role, and finding a new role as a teacher (Trautwein, 2018). According to McMillan \& Gordon (2017), five spaces with the emancipatory potential to assist the academic in her/his professional development by being and becoming a university teacher include communities of practice, academic freedom, position statements, development opportunities, and a supportive environment. Researching the lived space of the HET has the potential to help the academic community and society understand the landscapes in which HETs conduct their academic roles and are loyal to the HE mission. 
Researchers have conducted studies about HETs' attitudes, opinions, experiences, and perceptions. Kálmán, Tynjälä, \& Skaniakos (2019) studied patterns of the approaches of university teachers from Finland and Hungary to teaching, professional development, and perceived departmental cultures. From results, four patterns emerged: (1) experimenters with diverse teaching approaches; (2) experimenters perceiving their department's culture as most supportive and collaborative; (3) individualistic knowledge-focused teachers; and (4) student-thinking oriented but professionally unintegrated teachers. King (2004), Behar-Horenstein et al. (2008) speak about HETs' professional development by providing two arguments. Firstly, HETs' professional development might be considered as an explicit part of professional practice, linked to the requirements of membership of a professional body. Secondly, professional development is part of HETs' working lives. Hagenauera \& Volet (2014) performed research on the relationship between students and teachers in $\mathrm{HE}$ across three main areas: the quality of this relationship, its consequences, and its antecedents. The HET's role in promoting student engagement is oriented to three dimensions: i) behavioral engagement (actions, observations), ii) emotional engagement (feeling, internal emotions), and iii) cognitive engagement (thoughts, internal cognitions). Ferman (2002) identified a wide range of collaborative and individual activities of HETs including working with an educational designer, attending workshops, discussions with peers, presenting at conferences, being mentored, and undertaking professional reading. Such variation of activities is recognized by those offering guidelines and recommendations for professional development in higher education. Stenfors-Hayes (2011) provided advice and reflections for a university teacher beginning an academic career with the focus on balancing teaching and research.

All these studies show that HETs' practices are studied through lenses of methodologies, institutional cultures, learning, or matching the roles of a teacher and scholar. But research on being a HET, internationally and nationally, does not focus on specific aspects such as the professional space and the professional body as experienced by HETs in academia.

The lived body, according to van Manen (2014), guides the reflection to ask how the body is experienced and how do desires, fears, expectations and etc. incarnate themselves in the world in which HETs dwell? The lived professional body refers to fact that a person lives and experiences this world through his/her body (Adams, 2006). "In our physical or bodily presence, we both reveal something about ourselves and we always conceal something at the same time - not necessarily consciously or deliberately, but rather in spite of ourselves" (van Manen, 1990, 103). The lived professional body of the HET is developed or created through the variety of interactions from the particular discipline and the institution to students, colleagues, scholars and professional communities (Tight, 2002). These interactions allow the HET to share knowledge, to expect help, support and intellectual input form the self and others, and to integrate different academic roles (Ferman, 2002). Thus, the lived professional body is related to acting (developing, 
creating, implementing, sharing, etc.) and may not include the physical component as compulsory. The lived body is sensed, perceived, and experienced (Merleau-Ponty, 2012; Dall'alba, 2009) socially, psychologically, morally, and professionally through acting (Lueddeke, 2003; Courneya, Pratt, \& Collins, 2008). So, in this context the particular research question is raised: What do professional space and professional body mean and how is it experienced by the higher education teacher?

Therefore, the manuscript relies on the position that teaching at the university level should not be considered a duty that just needs to be done by HET. It is a crucial part of academia, and it is essential that HETs portray it as such. Through teaching, HETs as scholars/researchers are responsible for the education of the next generation of educated citizens, who will use their own unique ideas and skill sets to advance their professional activity fields (Taliun, 2019).

The aim of this study was to examine the patterns of HETs' experiences that are meaningful with regard to a professional body and professional space within the HE.

\section{Methodology}

\section{Design}

In the research, qualitative design with phenomenological hermeneutics was applied according to Lindseth and Norberg (2004). This methodological version is based on the philosophical foundations of Heidegger (1962), Gadamer (1976), and Ricoeur (2003): essential meaning is something with which humans are familiar in the practices of life, and this familiarity has to be expressed through the way of living, actions, narratives, and reflections. For research purposes lived experience is fixed in interview texts, which are analyzed. Every interview transcends the text meaning to reveal essential traits of the interviewees' life worlds. Epoché or bracketing was accomplished. Within brackets are placed researchers' judgements about the facts in order to become open to narrated experiences by research participants and to the meaning implicit in this experience.

The phenomenological existences such as lived time, lived space, lived things, lived body, lived relationship (Merleau-Ponty, 1964, 2012; Adams, 2006; van Manen, 2014) are important notions in presenting findings and interpreting them. In this manuscript two existences - lived space and lived body - are provided as findings.

\section{Sample}

Purposeful sampling was implemented. The sample consisted of twelve research participants - scholars from universities in which they conduct roles of higher education 
teacher (HET) and a researcher. Selection criteria for research participants: Ph.D. in social sciences, working at university not less than five years. Eight scholars participated in the study - 1 man and 7 women, and the mean age was 45 years.

\section{Methods}

\section{Data collection}

The data were collected between February and December 2019. Data were collected by using semi-structured interviews. "A semi-structured life-world interview attempts to understand themes of the lived daily world from the subjects' own perspectives" (Kvale, 2007, 11).

The starting point of an interview was lived experience. Within this experience, interviewees were familiar with the meaning of particular phenomena, which was researched in the study. When interview participants talked about cases or situations in particular contexts, they were interested to narrate about it through reflecting and memorizing. Interview texts expressed interviewees' experiences. The interviews were not about the scientific subject matter, but about the specific meaning of experiences in regard to the researched phenomenon.

When the interviewees gave expression to their lived experiences in phenomenologic hermeneutic research then it was focused on the understandable meaning of these researched experiences. Experiences of actions, activities, reactions, and other aspects made research participants familiar with the phenomenon under study, and out of this familiarity they were able to discuss how to understand the (essence of the) researched phenomenon - being a higher education teacher.

The semi-structured interview consisted of three main open questions: i) What does it mean for you to be a teacher at university? ii) What does it mean for you to be a researcher at university? ii) What is the meaning of integrating these two roles - teacher and researcher - at university?

\section{Data analysis}

Data analysis consisted of several main steps (Lindseth \& Norberg, 2004):

1. Naïve reading was conducted by reading the text several times in order to grasp its meaning as a whole. The researchers were open in order it would speak to them. Researchers switched from a natural to a phenomenological attitude.

2. Thematic structural analysis performed in order to identify and formulate themes conveying an essential meaning of lived experience. Thus, every interview text was divided into meaning units that were excerpts of interviews. Themes are formulated as condensed descriptions in a way that discloses meaning. A meaning 
unit can be a sentence, several sentences, a paragraph or part of any length of interview text that conveys one meaning.

3. The meaning units are read through and reflected on and they are condensed by expressing the essential meaning as concisely as possible.

4. All condensed meaning units are read through and reflected on regarding similarities and differences. They are then sorted and abstracted to sub-themes, which are assembled to themes, which are assembled into main themes.

5. The meaning units are decontextualized from the interview texts as a whole. This is possible if the meaning units are long enough to contain one essential meaning. We sometimes find that a meaning unit contains more than one essential meaning, which entails a further division.

6. The themes are reflected on in relation to the naïve understanding and the research question. Naïve understanding means life-world of experience as lived by them, pre-theoretical.

\section{Ethics}

To ensure a pure description of data, researchers used phenomenologic bracketing. Before data were collected and analyzed, researchers set aside their potential prejudices and biases. Transcriptions of interviews, the structure of themes with subthemes, and the main theme within every interview, summary of the researchers' perceptions of every interview were discussed among researchers till the consensus regarding the final structure of every main theme. Research participants were asked to validate the content of main themes and provide additional comments if they found changes necessary. Nothing was changed by interviewees. Meanwhile, every interview text was analyzed autonomously by both researchers and then discussed until consensus was found regarding every subtheme, theme and the main theme. This strategy showed no big differences between two independent structural thematic analyses of interview texts. For validation, the whole process of analysis was checked with other scholars (who did not participate in the research) as a panel of experts. A triangulation of researchers helped to take into account different perspectives when analyzing the data. And then the final structure of the main themes was formed. 


\section{Findings}

\section{Living in a professional space}

The professional space of HETs is lived through specific relationships with professional activities, academic environment, scientific discipline, students, and information, and communication technologies.

Creating academic "I" holistically. The chosen academic profession and a specific environment as meaningful space in which $s /$ he is created as a HET holistically:

The chosen academic profession creates me. And the academic environment I am in creates me as well. Holistically. And it brings peace to my academic world (R8).

Creating an intellectual relationship with discipline. HET creates the relationship with the scientific discipline, which is an authentic intellectual space in which s/he finds the meaningful research topics, which require from HET to step into unknown what brings a joy of scientific discovery:

I really like to find some areas or topics that are little researched. To look at it from different angles and to find those so-called gaps, where is an empty space of particular research phenomenon (R4).

Contemplating for academic productivity. HET needs to be disconnected from routine and create the contemplative space in order to do the work productively:

Where are ideas born? Ideas are born in spaces that are strongly internalized in your subconsciousness. I need to be disconnected from the world routine, then I am immersed in the contemplative process. (R8)

It's up to me to decide, if I'm self-aware of giving myself as much space as I can, to do things creatively. I don't produce a lot of articles. If I write, I use the time as much as I need in order to do the job creatively (R7).

Reflecting through interactions with students. HET through interactions with students creates reflective space in which both sides learn from each other:

Everything starts from respect, because, in fact, students come with different perspectives. Those views may be different from my views, but I have this disposition, that these ideas can be completely different from my ideas. And I see, maybe there are some interesting points in it and maybe I look deeper to those ideas. There is important to accept and respect otherness and different views, different experiences, different way of thinking I encourage independent thinking, not just expressing any opinion, but to have some argument presented. Together we create reflective space (R4). 
Table 1

Living in Profession

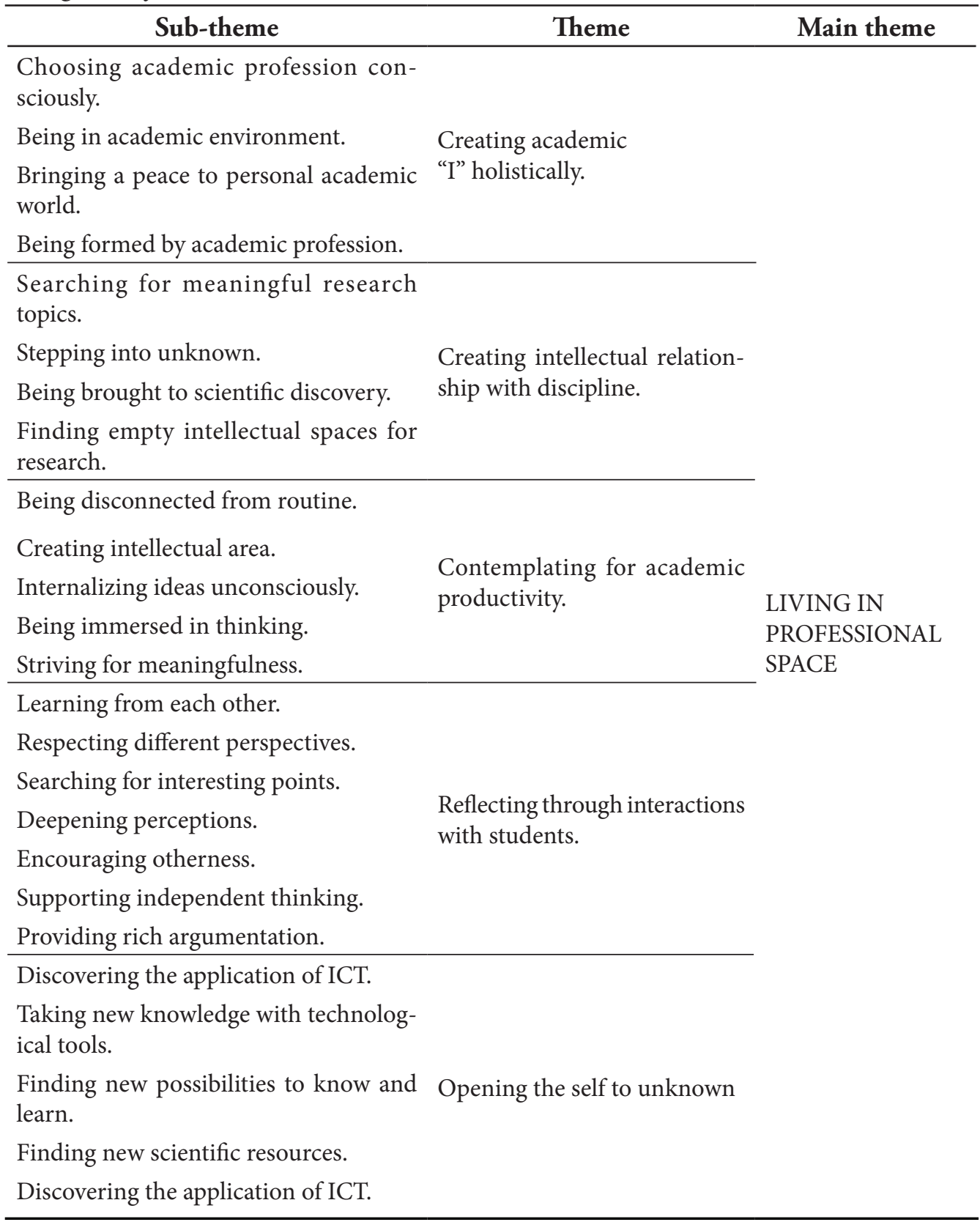


Opening the self to the unknown. The HET creates innovative space by using information and communication technologies (ICT) and this space provides to him/her possibilities to open the self to the unknown:

There are a lot of databases and internet resources which I can read and built my research. I think, that not taking all this knowledge from these sources it is like a sin. I create my innovative space through using information and communication technologies (R3).

\section{Creating professional body}

Becoming and being a HET requires a holistic view of oneself: how do I feel, how I react, what kind of things motivates me, etc. It brings perspective to see oneself not as a collection of multiple separate parts, but like a related whole. Creation of the professional body is experienced by the HET through authentic interactions with academy, colleagues, students, scientific discipline by creating, developing, forming the body of knowledge and knowing, which is never in the position of status quo.

Table 2

Creating Professional Body: Subthemes and Themes

\begin{tabular}{lll}
\hline \multicolumn{1}{c}{ Sub-theme } & \multicolumn{1}{c}{ Theme } & Main theme \\
\hline $\begin{array}{l}\text { Forming authentic knowledge. } \\
\text { Opening the self to growing. }\end{array}$ & $\begin{array}{l}\text { Sharing experiential } \\
\text { knowledge. }\end{array}$ & \\
$\begin{array}{l}\text { Providing internal embedded knowledge. } \\
\text { Growing through togetherness. }\end{array}$ & \\
\hline $\begin{array}{l}\text { Cooperating for academic support. } \\
\text { Forming social embodiment. }\end{array}$ & $\begin{array}{l}\text { Searching for } \\
\text { academic help } \\
\text { and input. }\end{array}$ & CREATING \\
$\begin{array}{l}\text { Creating strategy for activities. } \\
\text { Being in social communion. }\end{array}$ & \\
\hline $\begin{array}{l}\text { Experiencing overlap of responsibilities. } \\
\text { Disseminating knowledge. }\end{array}$ & \\
$\begin{array}{l}\text { Experiencing freedom. } \\
\text { Working through authentic path. }\end{array}$ & $\begin{array}{l}\text { Integrating } \\
\text { academic roles. }\end{array}$ \\
$\begin{array}{l}\text { Recognizing personal strengths and weaknesses. } \\
\text { Balancing between responsibilities and expec- } \\
\text { tations. }\end{array}$ &
\end{tabular}


Sharing experiential knowledge. The HET shares with students experiential knowledge and this creates the body of authentic knowledge:

Being a higher education teacher means to be authentic. Authentic, that I come to lectures and how I teach students. That I give not only knowledge from the level of intelligence, but give knowledge which are connected to my personal experience which I can share with them (R4).

Higher education teacher is open and seeks to grow, always learns and shares. I always learn from my students. I am open and want to grow together with them (R4).

Searching for academic help and input. The HET with colleagues or students forms the social body through cooperation in situations when s/he searches for academic help, which is focused on research, scientific discipline and/or academic input through particular activities:

I have to think what I will do next. I lack hands who can help me. Then I start to think about my colleagues and students. I ask for academic help, which means academic input (R6).

Together with students we make a research and they help me to collect data. It's added value. It means that I truly have a support from my students in research and they grow through it as researchers. We create social communion within the research ( $R 1)$.

Integrating academic roles. HET interaction with different, but interrelated and complementary roles such as teacher's and researcher's, develops the professional body:

I can't separate the roles of the researcher and teacher. I am not only a teacher at university. These roles overlap with each other and I need both of them (R2). If I would be only a researcher without teaching, I would consider my life not entirely meaningful. Especially in social sciences, I did not have the opportunity to disseminate scientific knowledge only as a teacher (R8).

Being in compliance with activities brings a strong connection between both teacher and researcher roles. These roles connect theory and practice: practical activities help to discover themes which are not researched (R4).

Discovering harmony in academic activities. HET interaction with the self requires discovering harmony in a variety of academic activities and that requires seeing things in a holistic way. Thus, the holistic personal body of the HET's "I" s/he forms through balancing between the work and leisure, personal and professional needs:

Then I do this in combination with other activities. I work here for several hours and then go for a walk. Sometimes I need to refuse something for achieving other things. Then it all comes together as a whole (R8).

I feel good when I am free to do everything at my own pace. But sometimes I work poorly. 'Poorly' I mean, that I feel bad and I let myself to be a human being. What is important, that I search for midpoint (R3). 


\section{Discussion}

\section{Living in a professional space}

Findings show that different relationships of HETs create lived spaces that do not have physical limits and they are contemplative, reflective, or innovative. But only the academic profession and academic environment create the HET.

Personal holistic space. HETs create their academic "I" through the academic profession, which incorporates scientific discipline and academic environment: it is a process in which HETs create their own academic identity. Research participants mention its holistic trait. This finding is different from the approach of Quigley (2011), who mentions that academic identity is a constantly shifting target, which differs for each individual academic. But findings of our research are in accordance with Henkel's (2005) concept of academic identity which is described as a function of the community membership that is grounded in interactions between the individual and the discipline, and higher education as an institution. Hence the creating of the academic "I" relates to professionalism (scientific subject), profession (HET), education and academic membership, and HE institution (academic environment).

Intellectual space. The intellectual may be a HET involved in the production of research-based outputs and usually has an academic background. Intellectuals may propose solutions for issues and gain authority. Intellectuals defend a system of particular values (Jennings \& Kemp-Welch, 1997). Intellectual relationship involves a person's ability to think and to understand ideas and information (dictionary.com, 2020). Findings showed that the HET continuously creates intellectual space through an authentic relationship with the discipline, which s/he represents through research topics that are focus on HET intellectual activities. Findings could be perceived through processes of the HET's intellectual development, which is based on continuous learning. This process is about how HETs organize their minds, ideas, and thoughts to make sense of the world they live in (Reverso Dictionary, 2020).

Contemplative space. The prestige of an academic institution is closely related to most measures of the quantity and quality of its scholarly outputs. Faculties and departments at more-prestigious HE institutions produce more of the scientific literature, receive more citations and scientific awards (Way, Morgan, Larremore, \& Clauset, 2019). In all academic fields, there are scholars who contribute to the research literature at exceptionally high levels of scientific productivity (Martinez, Floyd, \& Erichsen, 2011). HETs in our research speak about educational productivity, which is related to individual contemplation with being detached from work routine. This means that the HET needs the time of being with the self. The retrieval of askesis in the current era may be applied to contemplation. Underlying the rationale for such retrievals has been the recognition of the role of personal formation for transformative and mental well-being, whether acknowledged or not (Larrivee \& Echarte, 2017). 
Reflective space. A central issue in education is how the HET can inspire students to participate in the process of knowledge construction and to be a part of a community of inquiry in HE institution (2003). Findings of our research showed that HETs and students learn from each other through reflective learning interactions. Elbers (2003) provided the same attitude by accentuating that learning is the changing participation of students in reflective discourse.

Innovative space. Developments in educational technology have changed HE dynamics. ICT-mediated communication allows students to participate in interactive activities with their peers and HETs in a virtual environment. These tools are becoming so interactive and collaborative that they provide opportunities for HETs to achieve diverse educational goals (Murugaiah \& Thang, 2010). These ICT integration-based educational goals, according to our research, provides for students and HETs to participate in discoveries of the unknown through learning interactions.

\section{Creating the professional body}

The professional body is created through social interactions with the colleagues and students, and the HET's authentic interactions with the scientific discipline, which is embodied by the HET, HE institution in which the HET works and represents through scientific production and input.

HET-students. Our research findings highlight that the HET shares experiential authentic knowledge with students by creating the individual professional body of authentic knowledge. This idea is in concordance with Blume's (2017) thoughts that experiential knowledge is truth learned from individual authentic experience. But our research findings show that HETs declare experiential knowledge as developmental in regard to learning through interactions by sharing knowledge and growing from both sides. These findings are in opposition to Blume's (2017) who sees experiential knowledge as embodied which are oriented to here-and-now action rather than to the long-term development and systematic accumulation of knowledge.

Colleagues-HET-students. In our research HETs specify that they need academic help and support from colleagues, academics, and students and HETs do not clarify that such help is academic support. Namely, from these aspects consists an academic support, which refers to a wide variety of instructional methods, educational services, or resources provided to students in the effort to help them to accelerate their learning progress, catch up with their peers, meet learning standards, or generally to succeed in the HE institution (Academic Support, 2020). However, academic help or support must be used within specific contexts with specific examples, or additional explanation, because without it may be difficult to determine precisely what academic support or academic help is referring to (Balfanz et al., 2007).

HET-academia. The research identified that HETs declare that they continuously integrate roles and this helps them to create their professional body in regard to the 
scientific discipline which they represent and seek to harmonize their academic activities. Harmonization as applied to education is not synonymous with uniformity, standardization, regulation, condensation homogenization or unification (Woldegiorgis, 2013; Pedler, Yeigh, \& Hudson, 2020). Then integration and harmonization form a holistic picture of HETs' complex performance or academic professional activities that a part of creating the professional body. Mathieson (2019) adds that such integration provides for HETs to implement research-informed teaching; nevertheless, HETs could have different beliefs about learning and teaching.

\section{Conclusions}

The lived professional space refers to more than the physical space, because this is felt experiential space. The higher institution setting is the source of the higher education teacher's professional space, being a place with a specific atmosphere and a specific logic that has an influence on how the higher education teacher acts, behaves, and feels within the academic profession lenses. The lived professional space is an embodied space as the location where the higher education teacher's experience takes on academic professional form. Professional space is created through learning interactions or relationships with students, the self, and the scientific discipline. The lived professional space is regarded as the higher education teacher's intellectual, reflective, contemplative learning niche, which is continuously shaped by his/her exchange with the academic environment.

The lived professional body of the higher education teacher is a lived center of his/ her professional experience and a continuous process. The professional body is not the physical unit, but it is created or constructed by higher education teacher through interactions. Interactions with students and colleagues mean sharing experiential knowledge and searching for academic help or support through cooperation, and interactions with academy or higher education institutions mean integrating academic roles. In every type of interaction there is an external part, which is represented by visible interactions through academic activities as a social beings, and an internal part, which is invisible and means the higher education teacher's thinking, perceiving as a cognitive "I". 


\section{References}

Academic Support (2020). The glossary of education reform for journalists, parents, and community members. Retrieved June 12, 2020 from https://www.edglossary.org/academic-support/

Adams, M. (2006). Towards an existential phenomenological model of life span human development. Existential Analysis, 17(2), 261-279.

Anderson, C., \& Hounsell, D. (2007). Knowledge practices: 'doing the subject' in undergraduate courses. The Curriculum Journal, 18, 467-478. doi: 10.1080/09585170701687910

Balfanz, R., Herzog, L., \& Mac Iver, D. J. (2007). Preventing student disengagement and keeping students on the graduation path in urban middle-grades schools: early identification and effective interventions. Educational Psychologist, 42(4), 223-235. doi: 10.1080/00461520701621079

Behar-Horenstein, L., Schneider-Mitchell, G., \& Graff, R. (2008). Faculty perceptions of a professional development seminar. Journal of Dental Education, 72(4), 472-483. doi: 10.13140/ RG.2.2.13642.62408

Biggs, J. (1999). Teaching for quality learning at university. Buckingham: SRHE and Open University Press.

Blume, S. (2017). In search of experiential knowledge, innovation. The European Journal of Social Science Research, 30(1), 91-103. doi: 10.1080/13511610.2016.1210505

Dictionary (2020). Intellectual relationship. In Dictionary com. dictionary. Retrieved June 2, 2020 from https://www.dictionary.com/browse/intellectual

Courneya, C., Pratt, D., \& Collins, J. (2008). Through what perspective do we judge the teaching of peers? Teaching and Teacher Education, 24, 69-79.

Dall'alba, G. (2005). Improving teaching: enhancing ways of being university teachers. Higher Education Research \& Development, 24(5), 361-372. doi: 10.1080/07294360500284771

Dall'alba, G. (2009). Learning professional ways of being: ambiguities of becoming. Educational Philosophy and Theory, 41(1), 34-45. doi: 10.1111/j.1469-5812.2008.00475.x

Elbers, E. (2003). Classroom interaction as reflection: learning and teaching mathematics in a community of inquiry. Educational Studies in Mathematics, 54(1), 77-99. doi: 10.1023/B:EDUC.0000005211.95182.90

Ferman, T. (2002). Academic professional development practice: what lecturers find valuable. International Journal for Academic Development, 7(2), 146-158. doi: 10.1080/1360144032000071305

Gadamer, H.-G. (1976). Philosophical Heremeneutics. Berkeley: University of California Press.

Gagliano Taliun, S. A. (2019). Teaching at the university level is not a hassle. Nature. Retrieved June 2, 2020 from: https://www.nature.com/articles/d41586-019-02928-3.

Henkel, M. (2005). Academic identity and autonomy in a changing policy environment. Higher Education, 49(1/2), 155-176. doi: 10.1007/s10734-004-2919-1

Heidegger, M. (1962). Being and time. New York: Harper. 
Jennings, J, \& Kemp-Welch, T. (1997). The century of the intellectual: From Dreyfus to Salman Rushdie. In J. Jennings, Welch, A. Kemp (Eds), Intellectuals in Politics: From the Dreyfus affair to Salman Rushdie. (pp. 1-21). London and New York: Routledge.

Kálmán, O., Tynjälä, P., \& Skaniakos, T. (2019). Patterns of university teachers' approaches to teaching, professional development and perceived departmental cultures. Teaching in Higher Education, 25(5), 595-614. doi: 10.1080/13562517.2019.1586667

King, H. (2004). Continuing professional development in higher education: What do academics do? Planet, 13(1), 26-29. Retrieved May 14, 2020 from https://doi.org/10.11120/plan.2004.00130026

Kvale, S. (2007). Doing interviews. Los Angeles: SAGE Publications.

Larrivee, D., \& Echarte, L. (2017). Contemplative meditation and neuroscience: prospects for mental health. Journal of Religion and Health, 57(6), 1-21. doi: 10.1007/s10943-017-0475-0

Lindblom-Ylänne, S., Trigwell, K., Nevgi, A., \& Ashwin, P. (2006). How approaches to teaching are affected by discipline and teaching context. Studies in Higher Education, 31(3), 285-298. doi: 10.1080/03075070600680539

Lindseth, A., \& Norberg, A. (2004). A phenomenological hermeneutical method for researching lived experience. Scandinavian Journal of Caring Sciences, 18(2), 145-153. doi: 10.1111/j.14716712.2004.00258.x

Lueddeke, G. R. (2003). Professionalising teaching practice in higher education: a study of disciplinary variation and 'teaching scholarship'. Studies in Higher Education, 28(2), 213-228. doi: 10.1080/0307507032000058082

Martinez, R. S., Floyd, R. G., \& Erichsen, W. (2011). Strategies and attributes of highly productive scholars and contributors to the school psychology literature: recommendations for increasing scholarly productivity. Journal of School Psychology, 49(6), 691-720. doi: 10.1016/j. jsp.2011.10.003

Mathieson, S. (2019). Integrating research, teaching and practice in the context of new institutional policies: a social practice approach. Higher Education, 78, 799-815. doi: 10.1007/s10734-01900371-x

McMillan, W., \& Gordon, N. (2017). Being and becoming a university teacher. Higher Education Research \& Development, 36(4), 777-790. doi: 10.1080/07294360.2016.1236781

Merleau-Ponty, M. (1964). Signs. R. C. McCleary (Transl. ed.). Evanston, I. L.: Northwestern University Press.

Merleau-Ponty, M. (2012). The Phenomenology of Perception. D. A. Landes (Transl. ed.). London; New York: Routledge.

Miron, M., \& Segal, E. (1978). “The Good university teacher” as perceived by the student. Higher Education, 7(1), 27-34. doi: 10.1007/ BF00129788.

Murugaiah, P., \& Thang, S. M. (2010). Development of interactive and reflective learning among Malaysian online distant learners: an ESL instructor's experience. International Review of Research in Open and Distance Learning, 11(3), 21-41. doi: 10.19173/irrodl.v11i3.842 
Pedler, M., Yeigh, T., \& Hudson, S. (2020). The teachers' role in student engagement: a review. Australian Journal of Teacher Education, 45(3), 48-62. Retrieved May 5, 2020 from: https:// ro.ecu.edu.au/ajte/vol45/iss3/4

Quigley, S. A. (2011). Academic identity: A modern perspective. Educate, 11(1), 20-30.

Reverso Dictionary (2020). Intellectual relationship. In Reverso Dictionary.com. Retrieved June 2,

2020 from: https:/dictionary.reverso.net/english-cobuild/intellectual+space

Ricoeur. P. (2003). The rule of metaphor: The creation of meaning in language. London: Routledge Classics.

Stenfors-Hayes, T. (2011). Being and becoming a teacher in medical education. [Doctoral dissertation, Karolinska Institutet]. Stockholm. https://pubtestnew.kib.ki.se/xmlui/handle/10616/40523

Tight, P. (2002). Being a teacher in higher education. Suffolk: SRHE and Open University Press. Trautwein, C. (2018). Academics' identity development as teachers. Teaching in Higher Education, 23(8), 995-1010. doi: 10.1080/13562517.2018.1449739

van Manen, M. (2014). Phenomenology of practice. Walnut Creek, CA: Left Coast Press Inc.

Way, S. F., Morgan, A. C., Larremore, D. B., \& Clauset, A. (2019). Productivity, prominence, and the effects of academic environment. Proceedings of the National Academy of Sciences of the United States of America, 116(22), 10729-10733. doi: 10.1073/pnas.1817431116

Woldegiorgis, E. T. (2013). Conceptualizing harmonization of higher education systems: the application of regional integration theories on higher education studies. Higher Education Studies, 3(2), 12-23. doi: 10.5539/hes.v3n2p12

\title{
Būti dèstytoju aukštajame moksle: gyvenimas profesinèje erdvèje ir profesinio kūno kūrimas
}

\author{
Žydžiūnaitė Vilma ${ }^{1}$, Daugèla Marius ${ }^{2}$
}

1 Vytauto Didžiojo universitetas, Švietimo akademija, K. Donelaičio g. 58, 44248, Kaunas, Lietuva,
vilma.zydziunaite@vdu.lt
2 Vytauto Didžiojo universitetas, Švietimo akademija, K. Donelaičio g. 58, 44248, Kaunas, Lietuva,
vilma.zydziunaite@vdu.lt

\section{Santrauka}

Aukštajame moksle dirbantys dèstytojai naudojasi savo nuostatomis, lūkesčiais, patirtimi, kompetencijomis, suvokimais, kurie daro įtaką jų dèstymui ir studentų mokymuisi. Tyrimas atsako ị konkretų tyrimo klausimą: „Ką reiškia aukštajame moksle dirbančiam dėstytojui patirti profesinę erdvę ir profesinị kūną?". Tyrime buvo naudojamas kokybinis fenomenologinès hermeneutikos dizainas. Tikslinè atranka buvo vykdoma imant pusiau struktūruotus interviu iš aštuonių aukštajame moksle dirbančių dėstytojų. Tyrimas atskleidė, kad profesinè erdvė 
išgyvenama per specifinius ryšius su profesine veikla, akademine aplinka, moksline disciplina, studentais ir informacinėmis bei ryšių technologijomis. O profesinio kūno kūrimas yra patiriamas per autentišką sąveiką su akademija, kolegomis, studentais, kuriant mokslinę discipliną, tobulinant, formuojant žinių ir žinojimo visumą, kuri niekada nėra status quo. Išvadose teigiama, kad aukštojo mokslo įstaiga yra aukštajame moksle dirbančio dèstytojo profesinès erdvès šaltinis, o gyvenama profesinė erdvė yra ịkūnijama erdvè, kurioje dėstytojo patirtis igyja akademinę profesinę formą. Gyvenamas profesinis kūnas yra gyvas dèstytojo profesinès patirties centras ir tai nèra fizinis vienetas, bet ji dėstytojas sukuria per sąveikas.

Esminiai žodžiai: būtis, aukštoji mokykla, aukštojo mokslo dèstytojas, sq̨veika (-os), fenomenologija, profesine erdvé, profesine savastis, studentai.

Gauta 20200626 / Received 26062020

Priimta 20200901 / Accepted 01092020 